\title{
Upaya Peningkatan Pengetahuan dan Sikap Siswa SMP dalam Pencegahan Penggunaan NAPZA
}

\author{
Heryanto Sumbung ${ }^{1}$, Evi Martha ${ }^{1}$ \\ ${ }^{1}$ Departemen Pendidikan Kesehatan dan Ilmu Perilaku Fakultas Kesehatan Masyarakat Universitas Indonesia
}

\section{ABSTRACT}

Background: Ransiki is a district in South Manokwari Regency which was a new division in West Papua Province. Junior high school students in Ransiki are at risk of drug use. An effort should be made to improve the knowledge and attitude of junior high school students as a form of prevention of drug use. This study aimed to improve knowledge and attitude for the prevention of drug use in junior high school students in Ransiki using the training module "Pengenalan Bahaya NAPZA bagi Kesehatan".

Method: This was a Pre Experimental study using the one group pre-test and posttest design. The study samples were 60 students. Samples were determined by purposive sampling. The intervention was conducted by providing module training for five meetings. The pre-test and post-test of students were analyzed using the Dependent T-test.

Results: The results showed there was a significant relationship between the mean score of students' knowledge before the intervention (39.44) and after the intervention (77.77) ( $p$-value $=0.0001)$. There was a significant relationship between the mean score of students' attitudes before the intervention (73.40) and after the intervention (82.40) ( $p$-value $=0.0001)$. The training module "Pengenalan Bahaya NAPZA bagi Kesehatan" can be used to improve students' knowledge and attitude to prevent drug use in junior high school students of South Manokwari Regency.
Correspondence

evie.martha@ui.ac.id

Article History

Received 19 January 2020

Revised 2 April 2020

Accepted 20 April 2020

Available Online 12 June 2020

Keywords

Knowledge

Attitude

Drugs

Adolescent

Junior high school

DOI

10.14710./jpki.15.2.42-50

\section{PENDAHULUAN}

Penyalahgunaan NAPZA setiap tahun semakin meningkat, dan pelajar merupakan salah satu kelompok rawan yang dapat menyalahgunakannya. Pelajar berada pada usia remaja yang memiliki emosi labil, dan merasa dirinya sudah dewasa sehingga ingin mencoba hal-hal yang belum mereka ketahui sebelumnya. ${ }^{1}$

World Drug Report (United Nation Office on Drugs and Crime) pada tahun 2017 menunjukkan adanya kecenderungan peningkatan jumlah pengguna narkoba dan jumlah orang dengan gangguan akibat penggunaan narkoba yang berusia 15-64 tahun dari tahun 2006 hingga 2015 di seluruh dunia. Pada tahun 2006, jumlah pengguna narkoba sebesar 208 juta orang dan jumlah orang dengan gangguan akibat penggunaan narkoba sebesar 26 juta orang. Angka tersebut diperkirakan mengalami peningkatan yang signifikan di tahun 2015 dengan jumlah pengguna narkoba mencapai 255 juta orang dan jumlah orang dengan gangguan akibat penggunaan narkoba mencapai 29,5 juta orang. Dari total penduduk dunia, perkiraan prevalensi pengguna narkoba pada kelompok umur tersebut meningkat secara perlahan dari $4,9 \%$ di tahun 2006 menjadi 5,3\% di tahun 2015.,3

Hasil survei penyalahgunaan dan peredaran gelap narkoba pada kelompok pelajar dan mahasiswa di 18 provinsi di Indonesia tahun 2016 menunjukkan bahwa sebesar $30 \%$ pelajar masih memiliki pengetahuan yang kurang tentang narkoba dan sebesar 60\% menunjukkan variasi sikap yang rendah terhadap narkoba. ${ }^{4}$ Penggunaan NAPZA diperkirakan dimulai dari umur 12 tahun atau bahkan dapat lebih awal. ${ }^{5}$ Hal tersebut menunjukkan bahwa siswa Sekolah Menengah Pertama (SMP) menjadi sasaran empuk dari penyebaran NAPZA. ${ }^{6}$ Sampai saat ini, penggunaan NAPZA pelajar masih tetap terjadi, salah satu dampak dari NAPZA yaitu menyerang fungsi otak yang dapat mengakibatkan daya ingat menurun, sulit berkonsentrasi, menimbulkan perasaan khayal, dan kemampuan belajar merosot, ${ }^{7}$

Papua Barat merupakan salah satu provinsi yang menjadi target peredaran dan penggunaan NAPZA. Prevalensi penggunaan narkoba di Papua Barat mencapai 1,57\% yang artinya 9.952 orang usia 10-59 tahun adalah pengguna narkoba, di mana untuk Papua Barat didominasi 
dengan ganja di urutan pertama, sabu urutan kedua, kemudian ekstasi dan juga obat-obat yang bersifat bahan adiktif seperti lem aibon. ${ }^{4}$

Adapun upaya-upaya yang telah dilakukan untuk mencegah penggunaan NAPZA pada siswa SMP antara lain pengembangan model konseling, ${ }^{8}$ pelaksanaan layanan informasi, ${ }^{9}$ dan uji coba kurikulum pendidikan lewat modul, ${ }^{10}$ pendidikan narkoba lewat ceramah, ${ }^{11}$ program pencegahan penggunaan narkoba berbasis sekolah yang mengintegrasikan teori perilaku terencana (TPB) dan keterampilan hidup bagi siswa SMP. ${ }^{12}$

Beberapa penelitian telah dilakukan, menunjukan adanya perubahan tingkat pengetahuan dan sikap positif terhadap penggunaan NAPZA pada remaja SMP setelah dilakukan edukasi tentang narkoba. ${ }^{13}$ Midford dalam penelitian mereka di London tentang pengurangan bahaya NAPZA di sekolah dengan percobaan memberikan perlakuan edukasi tentang NAPZA kepada siswa SMP menunjukkan hasil yang signifikan dalam peningkatan pengetahuan dan sikap. ${ }^{14}$ Selain itu dengan strategi edukasi yang benar akan menghasilkan dampak yang positif bagi remaja dan terjadi perubahan baik tingkat pengetahuan maupun sikap yang positif. ${ }^{15}$

Ransiki adalah salah satu distrik di Kabupaten Manokwari Selatan yang merupakan Kabupaten pemekaran baru di provinsi Papua Barat. Ransiki dijadikan sebagai lokasi transit (persinggahan) jalan darat ke beberapa distrik dan kabupaten sehingga berpotensi dalam peredaran NAPZA. Berdasarkan hasil observasi yang dilakukan oleh peneliti sejak tahun 2013 hingga 2015, ditemukan bahwa banyak siswa SMP di Ransiki yang menggunakan NAPZA seperti rokok, lem fox/aibon, bensin, alkohol, obat-obatan (dextromethorphan), obat batuk komix bahkan sampai penggunaan obat anti nyamuk autan.

Akibat dari penggunaan NAPZA yang semakin banyak di Ransiki, kalangan siswa SMP merupakan sasaran dari penelitian ini, sebab remaja awal merupakan generasi strategis untuk diberikan edukasi. Dampak buruk yang ditimbulkan dari penyalahgunaan NAPZA harus dapat dicegah sedini mungkin sehingga tidak menyebabkan pengaruh buruk yang berlanjut kepada generasi selanjutnya. $^{4}$ Penelitian tentang upaya meningkatkan pengetahuan dan sikap siswa tentang NAPZA di Ransiki juga belum pernah dilakukan sebelumnya, maka perlu untuk dilakukan sebuah penelitian sebagai upaya promosi kesehatan dalam meningkatkan pengetahuan dan sikap siswa SMP Ransiki tentang NAPZA yang selanjutnya diharapkan dapat mengurangi dan mencegah penggunaan NAPZA pada kalangan siswa SMP di Ransiki. Pemberian informasi yang benar tentang bahaya penggunaan NAPZA lewat pelatihan modul di sekolah diharapkan dapat mencegah penggunaan NAPZA pada siswa SMP di Ransiki.

\section{METODE}

Jenis penelitian ini adalah Pre Eksperimental dengan rancangan the one group pretest-posttest design untuk melakukan pengukuran terhadap pengetahuan dan sikap siswa SMP sebelum dan sesudah dilakukan perlakuan (intervensi) yang dilaksanakan pada bulan Maret - Mei 2018 di SMPN 02 Ransiki, Kabupaten Manokwari Selatan Provinsi Papua Barat.

Populasi dalam penelitian ini adalah siswa SMPN 02 Ransiki yang berjumlah 517 siswa. Sampel dalam penelitian ini adalah siswa SMPN 02 Ransiki yang memenuhi kriteria inklusi dan ekslusi. Kriteria inklusi yang digunakan adalah siswa kelas VII dan VIII SMPN 02 Ransiki, mendapatkan persetujuan dari orang tua untuk mengikuti pelatihan modul, mengikuti maksimal 5 kali pertemuan pelatihan atau minimal 3 kali pertemuan. Kriteria ekslusi meliputi siswa kelas VII dan VIII SMPN 02 Ransiki yang tidak hadir saat pertemuan pertama dan pertemuan ke lima atau hadir pada pertemuan pertama dan tidak mengikuti pertemuan ke-2 sampai ke-5, atau hadir pada pertemuan 1-4 namun tidak hadir saat pertemuan ke-5, atau hadir pada pertemuan pertama dan kelima tapi tidak mengikuti pertemuan kedua sampai keempat.

Sampel yang dibutuhkan dalam penelitian ini dihitung berdasarkan rumus uji hipotesis dua proporsi dari sampel berpasangan serta untuk mengantisipasi drop out selama penelitian maka perlu dilakukan perhitungan besar sampel untuk antisipasi drop out. Sampel dalam penelitian ini sebanyak 60 siswa yang dipilih secara purposive sampling yang bertujuan untuk mencegah bias replikasi sehingga diambil perwakilan 1 kelas dari kelas VII dan 1 kelas dari kelas VIII. Intervensi dalam penelitian ini adalah dengan memberikan pelatihan modul "Pengenalan Bahaya NAPZA bagi Kesehatan" selama 5 kali pertemuan. Pengetahuan dan sikap diukur menggunakan kuesioner (pre test dan post test). Modul pelatihan diadopsi dan dikembangkan dari Kemenkes. Sedangkan pelatihan menggunakan metode ceramah dan diskusi yang disampaikan oleh peneliti.

\section{HASIL DAN PEMBAHASAN}

Berdasarkan tabel 1 dapat diketahui bahwa sampel penelitian yang diperoleh sebanyak 60 siswa yang terdiri dari 30 siswa kelas VII dan 30 siswa kelas VIII SMPN 02 Ransiki. Tabel 1 menunjukkan bahwa usia terbanyak siswa adalah umur 14 tahun $(33,3 \%)$. Subjek penelitian terdiri dari kelas 7 (50\%) dan kelas 8 (50\%) yang didominasi oleh siswa perempuan $(66,7 \%)$. Sebanyak $40 \%$ orang tua siswa menamatkan pendidikan terakhir pada jenjang SMA. 
Sebagian besar siswa berstatus tinggal dengan orang tua (85\%) dan sebagian besar siswa menjawab belum pernah mendengarkan informasi tentang NAPZA $(56,7 \%)$.

Berdasarkan tabel 2, dari 60 subjek yang diamati, rata-rata pengetahuan siswa tentang NAPZA sebelum intervensi adalah 39,44 dan rata-rata pengetahuan setelah intervensi adalah 77,77. Dengan menggunakan uji $\mathrm{T}$ Dependen didapatkan nilai $\mathrm{p}$ sebesar 0,0001. Secara statistik ada perbedaan yang signifikan antara rata-rata pengetahuan siswa sebelum dengan sesudah intervensi. Ada peningkatan pengetahuan siswa setelah intervensi sebesar 38,33 .

Berdasarkan tabel 3 terlihat bahwa dari 60 subjek yang diamati, rata-rata sikap siswa terkait NAPZA sebelum intervensi adalah 73,40 dan rata-rata sikap setelah intervensi adalah 82,40. Dengan menggunakan uji $\mathrm{T}$ Dependen didapatkan nilai $p$ sebesar 0,0001. Secara statistik ada perbedaan yang signifikan antara rata-rata sikap siswa sebelum dengan sesudah intervensi. Ada perubahan sikap siswa setelah intervensi sebesar 9,00.

Tabel 4 menunjukkan bahwa berdasarkan jenis kelamin, nilai rata-rata pengetahuan siswa perempuan lebih tinggi dari siswa laki-laki. Rata-rata nilai perempuan adalah 39,37 dengan variasi 19,70 dan rata-rata nilai laki-laki adalah 36,25 dengan variasi 19,82. Berdasarkan kelas, nilai rata-rata pengetahuan siswa kelas VII lebih tinggi dari siswa kelas VIII. Rata-rata nilai kelas VII adalah 41,94 dengan variasi 20,23 sedangkan rata-rata nilai siswa kelas VIII adalah 34,72 dengan variasi 18,64. Berdasarkan status keterpaparan informasi, nilai rata-rata siswa yang tidak pernah terpapar informasi NAPZA lebih tinggi dari siswa yang pernah terpapar informasi NAPZA. Nilai rata-rata siswa yang tidak pernah tertapapar informasi NAPZA adalah 39,33 dengan variasi 22,33, sedangkan nilai rata-rata siswa yang pernah terpapar informasi NAPZA adalah 37,01 dengan variasi 15,73 . Berdasarkan usia, nilai rata-rata siswa berusia $\leq 13$ tahun lebih tinggi dari siswa berusia $>13$ tahun. Nilai rata-rata siswa berusia $\leq 13$ tahun adalah 42,03 dengan variasi 19,55 , sedangkan nilai rata-rata siswa berusia $>13$ tahun adalah 33,49 dengan variasi 19,02.

Berdasarkan pendidikan terakhir orang tua, nilai rata-rata siswa yang memiliki orang tua berlatar belakang pendidikan SMA hingga Sarjana lebih tinggi dari siswa yang memiliki orang tua berlatar belakang pendidikan tidak sekolah hingga tamatan SMP. Nilai rata-rata siswa yang memiliki orang tua berlatar belakang pendidikan SMASarjana adalah 40,54 dengan variasi 18,59 sedangkan nilai rata-rata siswa yang memiliki orang tua berlatar belakang pendidikan tidak sekolah-SMP adalah 34,78 dengan variasi 21,11. Berdasarkan status tinggal, nilai rata-rata siswa yang tinggal dengan orang tua lebih tinggi dari siswa yang tinggal dengan keluarga lain. Nilai rata-rata siswa yang tinggal dengan orang tua adalah 39,95 dengan variasi 19,81 sedangkan nilai rata-rata siswa yang tinggal dengan keluarga lain adalah 29,16 dengan variasi 16,66.

Pengetahuan tentang kesehatan merupakan apa yang diketahui oleh seseorang mengenai cara memelihara kesehatan diri orang tersebut. Pengetahuan untuk memelihara kesehatan seseorang meliputi pengetahuan tentang penyakit menular dan tidak menular, pengetahuan tentang faktor-faktor yang mempengaruhi kesehatan seseorang, pengetahuan tentang fasilitas pelayanan kesehatan dan pengetahuan unuk bagaimana menghindari kecelakaan. ${ }^{16}$ Adapun faktor-faktor yang mempengaruhi pengetahuan yaitu faktor internal dan faktor eksternal. Faktor internal meliputi pendidikan, pekerjaan, umur sedangkan faktor eksternal meliputi lingkungan dan budaya. ${ }^{17}$

Tabel 1. Karakteristik responden

\begin{tabular}{|c|c|c|}
\hline Karakteristik & $\begin{array}{l}\text { Jumlah } \\
(\mathrm{n}=60)\end{array}$ & $\begin{array}{l}\text { Persentase } \\
\quad(\%)\end{array}$ \\
\hline \multicolumn{3}{|l|}{ Umur } \\
\hline 11 tahun & 1 & 1,7 \\
\hline 12 tahun & 14 & 23,3 \\
\hline 13 tahun & 19 & 31,7 \\
\hline 14 tahun & 20 & 33,3 \\
\hline$\geq 15$ tahun & 6 & 10 \\
\hline \multicolumn{3}{|l|}{ Jenis kelamin } \\
\hline Laki-laki & 20 & 33,3 \\
\hline Perempuan & 40 & 66,7 \\
\hline \multicolumn{3}{|l|}{ Kelas } \\
\hline VII & 30 & 50 \\
\hline VIII & 30 & 50 \\
\hline \multicolumn{3}{|c|}{ Pendidikan terakhir orang tua } \\
\hline Tidak Sekolah & 2 & 3,3 \\
\hline $\mathrm{SD}$ & 7 & 11,7 \\
\hline SMP & 14 & 23,3 \\
\hline SMA & 24 & 40 \\
\hline $\mathrm{S} 1$ & 7 & 11,7 \\
\hline $\mathrm{S} 2$ & 5 & 8,3 \\
\hline $\mathrm{S} 3$ & 1 & 1,7 \\
\hline \multicolumn{3}{|l|}{ Status Tinggal } \\
\hline Orang Tua & 51 & 85 \\
\hline Om dan Tante & 8 & 13,3 \\
\hline Kakek dan Nenek & 1 & 1,7 \\
\hline Teman & 0 & 0 \\
\hline Sendiri & 0 & 0 \\
\hline \multicolumn{3}{|l|}{$\begin{array}{l}\text { Keterpaparan Informasi } \\
\text { tentang NAPZA }\end{array}$} \\
\hline Pernah & 26 & 43,3 \\
\hline Tidak Pernah & 34 & 56,7 \\
\hline
\end{tabular}


Tabel 2. Hasil uji perbedaan pengetahuan

\begin{tabular}{lccccc}
\hline \multicolumn{1}{c}{ Variabel } & Rata-rata & Simpang baku & Nilai $\mathrm{p}$ & CI 95\% & Min-max \\
\hline Pengetahuan & & & & & $8,33-83,33$ \\
Pre Test & 39,44 & 18,89 & 0,0001 & $-43,40-$ & $29,17-100,00$ \\
Post Test & 77,77 & 22,84 & & $-33,26$ & \\
Selisih & 38,33 & & & & \\
\hline
\end{tabular}

Keterangan: Skala 0-100

Tabel 3. Hasil uji perbedaan sikap

\begin{tabular}{lccccc}
\hline \multicolumn{1}{c}{ Variabel } & Rata-rata & Simpang baku & Nilai p & CI 95\% & Min-max \\
\hline Sikap & & & & $-11,62-$ & $25,00-94,44$ \\
Pre Test & 73,40 & 14,42 & 0,0001 & $-6,37$ & $58,33-97,22$ \\
Post Test & 82,40 & 10,38 & & &
\end{tabular}

Keterangan: Skala 0-100

Tabel 4. Perbedaan karakteristik responden dengan selisih rata-rata pengetahuan siswa

\begin{tabular}{|c|c|c|c|c|c|c|c|c|c|}
\hline \multirow[t]{2}{*}{$\begin{array}{c}\text { Karakteristik } \\
\text { Responden }\end{array}$} & \multirow[t]{2}{*}{$\mathrm{n}$} & \multicolumn{2}{|c|}{ Sebelum } & \multicolumn{2}{|c|}{ Sesudah } & \multicolumn{2}{|c|}{$\begin{array}{l}\text { Selisih Pengetahuan } \\
\text { Sebelum Sesudah }\end{array}$} & \multirow[t]{2}{*}{ CI 95\% } & \multirow[t]{2}{*}{ Nilai $\mathrm{p}$} \\
\hline & & $\begin{array}{l}\text { Rata- } \\
\text { rata }\end{array}$ & $\begin{array}{c}\text { Simpang } \\
\text { Baku }\end{array}$ & $\begin{array}{c}\text { Rata- } \\
\text { rata }\end{array}$ & $\begin{array}{c}\text { Simpang } \\
\text { Baku }\end{array}$ & $\begin{array}{c}\text { Rata- } \\
\text { rata }\end{array}$ & Simpang Baku & & \\
\hline \multicolumn{10}{|l|}{ Jenis Kelamin } \\
\hline Laki-laki & 20 & 36,66 & 20,43 & 72,91 & 26,81 & 36,25 & 19,82 & $-13,94$ & 0,565 \\
\hline Perempuan & 40 & 40,83 & 18,17 & 80,20 & 20,51 & 39,37 & 19,70 & 7,67 & \\
\hline \multicolumn{10}{|l|}{ Kelas } \\
\hline VII & 30 & 38,88 & 20,39 & 80,83 & 22,03 & 41,94 & 20,23 & $-2,83$ & 0,156 \\
\hline VIII & 30 & 40,00 & 17,59 & 74,72 & 22,59 & 34,72 & 18,64 & 17,27 & \\
\hline \multicolumn{10}{|c|}{ Keterpaparan informasi } \\
\hline Pernah & 26 & 48,71 & 16,57 & 85,73 & 16,07 & 37,01 & 15,73 & $-12,16$ & 0,639 \\
\hline Tidak Pernah & 34 & 32,35 & 17,61 & 71,69 & 25,47 & 39,33 & 22,33 & 7,52 & \\
\hline \multicolumn{10}{|l|}{ Usia } \\
\hline$\leq 13$ Tahun & 34 & 42,64 & 19,89 & 84,68 & 18,59 & 42,03 & 19,55 & $-1,53$ & 0,095 \\
\hline$>13$ Tahun & 26 & 35,25 & 16,96 & 68,74 & 25,00 & 33,49 & 19,02 & 18,61 & \\
\hline \multicolumn{10}{|c|}{ Pendidikan terakhir orang tua } \\
\hline $\begin{array}{l}\text { Tidak } \\
\text { Sekolah-SMP }\end{array}$ & 23 & 33,64 & 15,33 & 68,47 & 24,45 & 34,78 & 21,11 & $-16,17$ & 0,273 \\
\hline SMA-Sarjana & 37 & 43,01 & 20,17 & 83,55 & 20,00 & 40,54 & 18,59 & 4,65 & \\
\hline \multicolumn{10}{|l|}{ Status Tinggal } \\
\hline Orang Tua & 51 & 41,09 & 18,96 & 81,04 & 21,26 & 39,95 & 19,81 & $-3,25$ & 0,130 \\
\hline Keluarga Lain & 9 & 30,09 & 16,37 & 59,26 & 23,82 & 29,16 & 16,66 & 24,83 & \\
\hline
\end{tabular}

Keterangan: Skala 0-100

Distribusi responden pada hasil pre test dan post test berdasarkan pengetahuan menunjukkan bahwa pertanyaan yang dijawab benar oleh sebagian besar siswa adalah pada pertanyaan tentang cara yang baik menolak ajakan atau tawaran teman jika diberikan NAPZA. Jika melihat hasil pre test dan post test, terdapat peningkatan jawaban benar pada setiap item pertanyaan pengetahuan dan terdapat penurunan jawaban salah pada setiap pertanyaan pengetahuan. Hal ini sejalan dengan studi yang dilakukan oleh Shekarchizadeh bahwa ada hubungan pengetahuan dengan pendidikan tentang NAPZA. ${ }^{18}$

Hasil uji perbedaan karakteristik responden dengan selisih rata-rata pengetahuan siswa menunjukkan bahwa nilai rata-rata pengetahuan siswa perempuan lebih tinggi dari siswa laki-laki. Hal ini dapat disebabkan karena siswa perempuan lebih aktif mencatat materi yang 
disampaikan serta aktif pada saat mengikuti kegiatan pelatihan. Nilai rata-rata pengetahuan kelas VII lebih tinggi dari kelas VIII dapat disebabkan karena mayoritas siswa kelas VII adalah anak-anak bukan asli Papua sehingga cara penangkapan materi yang diberikan lebih cepat.

Nilai rata-rata siswa yang tidak pernah terpapar informasi NAPZA lebih tinggi dari siswa yang pernah terpapar informasi NAPZA. Hal tersebut dapat disebabkan oleh seberapa besar keterpaparan informasi NAPZA. Apabila hanya satu kali terpapar, kemungkinan tidak akan bertahan lama. Berbeda dengan siswa yang tidak pernah mendengarkan informasi NAPZA sebelumnya, ketika mengikuti pelatihan yang dilakukan secara teratur selama lima minggu dapat mengingatkan mereka terus-menerus tentang informasi NAPZA.

Nilai rata-rata siswa berusia $\leq 13$ tahun lebih tinggi dari siswa berusia $>13$ tahun dapat disebabkan oleh mayoritas siswa yang berusia $\leq 13$ tahun merupakan siswa kelas VII, dimana mayoritas siswa kelas VII adalah siswa yang bukan asli Papua. Nilai rata-rata siswa yang memiliki orang tua berlatar belakang pendidikan SMA-Sarjana lebih tinggi dari siswa yang memiliki orang tua berlatar belakang pendidikan tidak sekolah-SMP kemungkinan disebabkan oleh semakin tinggi pendidikan orang tua maka semakin baik pola asuh dan informasi yang diberikan ke anak. Selain itu 40\% kecerdasan anak ditentukan oleh tingkat kepintaran orang tua. Nilai rata-rata siswa yang tinggal dengan orang tua lebih tinggi dari siswa yang tinggal dengan keluarga lain. Menurut hasil penelitian dari BNN dan PPKUI di tahun 2016 menyebutkan bahwa anak yang tidak tinggal dengan orang tua berisiko terpapar dengan peer group. $^{4}$

Pada pengelompokkan pertanyaan pengetahuan tentang pengertian NAPZA, bahaya NAPZA, faktor-faktor dan cara pencegahan NAPZA serta faktor risiko dari penggunaan NAPZA terdapat perubahan yang signifikan pada hasil sebelum dan sesudah intervensi. Hal tersebut menandakan bahwa setiap topik materi yang diberikan kepada siswa dapat diterima dengan baik. Penelitian yang dilakukan oleh Komaladewi di tahun 2016 menunjukkan bahwa salah satu keberhasilan dari perubahan pengetahuan siswa disebabkan karena bahan ajar atau seperangkat materi yang disusun secara sistematis dan dijadikan sebagai pedoman dalam proses pelatihan atau pembelajaran. Penelitian lain juga mengemukakan bahwa bahan ajar (modul) memungkinkan siswa dapat mempelajari suatu kompetensi secara utuh atau terpadu sehingga materi pembelajaran dapat tersampaikan dengan baik dan siswa memiliki aktivitas belajar yang baik. ${ }^{19}$

Berdasarkan hasil penelitian yang telah didapatkan terbukti dengan memberikan intervensi berupa pelatihan modul "Pengenalan Bahaya NAPZA bagi Kesehatan" dapat meningkatkan pengetahuan siswa SMPN 02 Ransiki dalam upaya pencegahan pengunaan NAPZA. Intervensi yang diberikan kepada siswa berupa pelatihan modul "Pengenalan Bahaya NAPZA bagi Kesehatan" yang bertujuan sebagai salah satu upaya dalam pencegahan penggunaan NAPZA pada siswa SMP. Dalam pelatihan ini siswa diberikan pengetahuan tentang definisi dan jenis-jenis NAPZA, dampak negatif yang ditimbulkan dari penggunaan NAPZA, faktor-faktor yang menyebabkan penggunaan NAPZA dan cara pencegahannya. Pelatihan ini dilakukan oleh peneliti sebagai fasilitator dan siswa sebagai partisipan. Selama pelatihan berlangsung, siswa sebagai responden sekaligus partisipan dalam penelitian ini selalu diajak untuk berpartisipasi aktif dalam setiap pertemuan. Keterlibatan siswa atau partisipasi aktif selama kegiatan pelatihan merupakan aspek yang sangat penting dalam meningkatkan efektivitas suatu intervensi. ${ }^{20}$

Skinner dalam teori S-O-R mengatakan bahwa perilaku merupakan hasil reaksi atau respons seseorang terhadap stimulus/rangsangan dari luar. Dengan demikian perilaku manusia terjadi melalui proses respons yang terdiri dari dari 2 jenis respons yaitu respondent respons (reflektif) yaitu respon yang ditimbulkan oleh rangsangan-rangsangan tertentu yang disebut eliciting stimuli karena menimbulkan reaksi-reaksi yang relatif tetap dan operant respons (instrumental respons) yakni respon yang timbul dan berkembang kemudian diikuti oleh stimulus atau rangsangan yang lain. Perangsang yang terakhir disebut reinforcing stimuli atau reinforcer sebab berfungsi dalam memperkuat respon. Berdasarkan teori SOR, pengetahuan dikelompokkan dalam perilaku tertutup (covert behavior) sebab respon terhadap stimulus yang diberikan belum dapat diamati oleh orang lain. ${ }^{23}$

Pengetahuan siswa SMPN 02 Ransiki mengalami perubahan peningkatan ( $\mathrm{p}$ value 0,0001 ) dengan nilai ratarata pre test yaitu 39,44, meningkat pada saat post test menjadi 77,77. Berdasarkan teori S-O-R di atas, faktor yang berpengaruh dalam perubahan pengetahuan siswa adalah diberikannya stimulus (modul pelatihan) yang di dalamnya terdiri dari materi-materi tentang pengenalan dan bahaya NAPZA, faktor penggunaan dan cara pencegahannya. Selain dari materi-materi yang diberikan, pengaruh metode yang digunakan seperti brainstorming, games, diskusi, role play dan tugas-tugas yang diberikan merupakan elemenelemen pendukung dalam keberhasilan intervensi ini.

Hasil penelitian yang ada, didukung oleh beberapa penelitian serupa yang menyebutkan bahwa pendidikan kesehatan lewat penggunaan modul pelatihan tentang NAPZA efektif dalam meningkatkan pengetahuan siswa ( $p$ value $0,0001<0,05$ ). Selain itu, penelitian lain pada siswa di Madrasah Aliyah Miftahul Jannah Palangkaraya menunjukkan bahwa pendidikan kesehatan dengan 
menggunakan modul pelatihan memberikan pengaruh yang signifikan terhadap tingkat pengetahuan responden ( $\mathrm{p}$ value $0,0001<0,05) .^{20,22}$

Hasil penelitian ini menunjukkan adanya perubahan pengetahuan yang terjadi pada siswa SMPN 02 di Ransiki dalam upaya mencegah penggunaan NAPZA. Namun upaya yang dilakukan tidaklah cukup dan berakhir di sini, upaya pencegahan yang berkelanjutan harus tetap dilakukan demi berhasilnya program pencegahan NAPZA pada siswa atau remaja.

Tabel 5 menunjukkan bahwa berdasarkan jenis kelamin, nilai rata-rata sikap siswa perempuan terkait NAPZA lebih tinggi dari siswa laki-laki. Rata-rata nilai perempuan adalah 9,54 dengan variasi 9,94 dan rata-rata nilai laki-laki adalah 7,91 dengan variasi 10,75 . Berdasarkan kelas, nilai rata-rata sikap siswa kelas VIII lebih tinggi dari siswa kelas VII. Rata-rata nilai kelas VIII adalah 10,36 dengan variasi 12,18 sedangkan rata-rata nilai siswa kelas 7 adalah 7,63 dengan variasi 7,59. Berdasarkan status keterpaparan informasi, nilai rata-rata siswa yang tidak pernah terpapar informasi NAPZA lebih tinggi dari siswa yang pernah terpapar informasi NAPZA. Nilai ratarata siswa yang tidak pernah terpapar informasi NAPZA adalah 9,14 dengan variasi 11,60 sedangkan nilai rata-rata siswa yang pernah terpapar informasi NAPZA adalah 8,81 dengan variasi 8,12 . Berdasarkan usia, nilai rata-rata siswa berusia $>13$ tahun lebih tinggi dari siswa berusia $\leq 13$ tahun. Nilai rata-rata siswa berusia $>13$ tahun adalah 11,85 dengan variasi 13,88 sedangkan nilai rata-rata siswa berusia $\leq 13$ tahun adalah 6,82 dengan variasi 5,22.

Berdasarkan pendidikan terakhir orang tua, nilai rata-rata siswa yang memiliki orang tua berlatar belakang pendidikan tidak sekolah hingga tamat SMP lebih tinggi dari siswa yang memiliki orang tua berlatar belakang pendidikan SMA hingga sarjana. Nilai rata-rata siswa yang memiliki orang tua berlatar belakang pendidikan tidak sekolah-SMP adalah 11,71 dengan variasi 13,49, sedangkan nilai rata-rata siswa yang memiliki orang tua berlatar belakang pendidikan SMA-Sarjana adalah 7,31 dengan variasi 7,09. Berdasarkan status tinggal, nilai rata-rata siswa yang tinggal dengan keluarga lain lebih tinggi dari siswa yang tinggal dengan orang tua. Nilai rata-rata siswa yang tinggal dengan keluarga lain adalah 15,12 dengan variasi 17,79 sedangkan nilai rata-rata siswa yang tinggal dengan orang tua adalah 7,92 dengan variasi 7,95.

Tabel 5. Perbedaan karakteristik responden dengan selisih rata-rata sikap siswa

\begin{tabular}{|c|c|c|c|c|c|c|c|c|c|}
\hline \multirow[t]{2}{*}{$\begin{array}{c}\text { Karakteristik } \\
\text { Responden }\end{array}$} & \multirow[t]{2}{*}{$\mathrm{n}$} & \multicolumn{2}{|c|}{ Sebelum } & \multicolumn{2}{|c|}{ Sesudah } & \multicolumn{2}{|c|}{$\begin{array}{c}\text { Selisih Sikap } \\
\text { Sebelum Sesudah }\end{array}$} & \multirow[t]{2}{*}{ CI 95\% } & \multirow[t]{2}{*}{$\begin{array}{c}\text { Nilai } \\
\mathrm{p}\end{array}$} \\
\hline & & $\begin{array}{l}\text { Rata- } \\
\text { rata }\end{array}$ & $\begin{array}{c}\text { Simpang } \\
\text { Baku }\end{array}$ & $\begin{array}{c}\text { Rata- } \\
\text { rata }\end{array}$ & $\begin{array}{l}\text { Simpang } \\
\text { Baku }\end{array}$ & $\begin{array}{l}\text { Rata- } \\
\text { rata }\end{array}$ & $\begin{array}{l}\text { Simpang } \\
\text { Baku }\end{array}$ & & \\
\hline \multicolumn{10}{|l|}{ Jenis Kelamin } \\
\hline Laki-laki & 20 & 71,66 & 14,37 & 79,58 & 9,72 & 7,91 & 10,75 & $-7,23$ & 0,562 \\
\hline Perempuan & 40 & 74,27 & 14,54 & 83,81 & 10,52 & 9,54 & 9,94 & 3,97 & \\
\hline \multicolumn{10}{|l|}{ Kelas } \\
\hline VII & 30 & 76,80 & 9,12 & 84,44 & 10,31 & 7,63 & 7,59 & $-7,98$ & 0,302 \\
\hline VIII & 30 & 70,00 & 17,77 & 80,37 & 10,21 & 10,36 & 12,18 & 2,51 & \\
\hline \multicolumn{10}{|l|}{$\begin{array}{l}\text { Keterpaparan } \\
\text { informasi }\end{array}$} \\
\hline Pernah & 26 & 76,12 & 10,86 & 84,93 & 8,98 & 8,81 & 8,12 & $-5,68$ & 0,900 \\
\hline Tidak Pernah & 34 & 71,32 & 16,49 & 80,47 & 11,07 & 9,14 & 11,60 & 5,00 & \\
\hline \multicolumn{10}{|l|}{ Usia } \\
\hline$\leq 13$ Tahun & 34 & 78,39 & 8,81 & 85,21 & 9,71 & 6,82 & 5,22 & $-10,88$ & 0,089 \\
\hline$>13$ Tahun & 26 & 66,88 & 17,61 & 78,73 & 10,24 & 11,85 & 13,88 & 0,81 & \\
\hline \multicolumn{10}{|l|}{$\begin{array}{l}\text { Pendidikan terakhir } \\
\text { orang tua }\end{array}$} \\
\hline Tidak Sekolah-SMP & 23 & 68,23 & 16,43 & 79,95 & 10,90 & 11,71 & 13,49 & $-1,82$ & 0,159 \\
\hline SMA-Sarjana & 37 & 76,61 & 12,16 & 83,93 & 9,88 & 7,31 & 7,09 & 10,62 & \\
\hline \multicolumn{10}{|l|}{ Status Tinggal } \\
\hline Orang Tua & 51 & 75,89 & 11,46 & 83,82 & 10,08 & 7,92 & 7,95 & $-20,95$ & 0,265 \\
\hline Keluarga Lain & 9 & 59,25 & 21,15 & 74,38 & 8,64 & 15,12 & 17,79 & 6,55 & \\
\hline
\end{tabular}

Keterangan: Skala 0-100 
Sikap terhadap kesehatan merupakan penilaian atau pendapat seseorang terhadap hal-hal yang berkaitan dengan bagaimana cara seseorang untuk memelihara kesehatan dirinya. Sikap terhadap kesehatan mencakup empat variabel yaitu sikap tentang penyakit menular dan tidak menular, sikap terhadap faktor-faktor yang terkait atau yang mempengaruhi kesehatan seseorang, sikap tentang fasilitas pelayanan kesehatan dan sikap untuk menghindari bahaya kecelakaan. ${ }^{16}$ Faktor-faktor yang berperan membentuk sikap seseorang antara lain pengalaman pribadi, pengaruh orang lain yang dianggap penting (role model), pengaruh kebudayaan, media massa, lembaga pendidikan dan lembaga agama serta faktor emosional. ${ }^{17}$

Pengukuran sikap dapat dilakukan secara langsung maupun tidak langsung. Pengukuran secara langsung dapat dilakukan dengan cara meminta pendapat atau pernyataan seseorang tentang sebuah objek sedangkan secara tidak langsung dapat dilakukan dengan pernyataan-pernyataan hipotesis dan kemudian ditanyakan pendapat seseorang dengan menggunakan sebuah instrumen (kuesioner). ${ }^{17}$

Remaja merupakan sebuah masa pencarian jati diri yang akan dialami setiap orang dalam proses tumbuh kembangnya. ${ }^{23}$ Hal yang sama dialami oleh para pelajar di Ransiki. Sikap positif atau negatif yang dimiliki merupakan hasil dari intervensi yang diterima. Remaja di Ransiki sangat mudah terpengaruh antara satu dengan lainnya. Selain itu pengaruh teknologi yang mulai pesat di daerah ini membuat anak-anak remaja sudah mulai terpapar dengan dunia luar dalam hitungan detik. Sebagaimana remaja merupakan masa akal balik, emosi remaja cenderung tidak stabil sehingga mempengaruhi kesalahan dalam pengambilan keputusan, seperti melakukan tindakan kekerasan dengan teman lainnya akibat emosi sesaat atau karena faktor pengaruh teman. Untuk mencegah hal-hal yang buruk terjadi pada remaja, maka perlu diberikan bimbingan atau pemahaman yang baik serta dukungan dalam melakukan kegiatan-kegiatan yang positif. ${ }^{24}$

Kecakapan hidup merupakan kecakapan yang dimiliki seseorang untuk mau dan berani menghadapi problema hidup dan kehidupan secara wajar tanpa merasa tertekan, kemudian secara proaktif dan kreatif mencari dan menemukan pemecahan untuk mengatasi problema tersebut. Kecakapan hidup dapat dikelompokkan dalam sepuluh aspek, yaitu kesadaran diri, empati, hubungan antarpersonal,kemampuan mengendalikan emosi, penyesuaian diri terhadap tekanan, berpikir kritis, berpikir kreatif, pengambilan keputusan, komunikasi yang efektif, dan pemecahan masalah. ${ }^{25}$ Program pencegahan masalah remaja dengan menggunakan pendekatan life skill telah berhasil menangani masalah remaja seperti penyalahgunaan NAPZA, kehamilan, kekerasan dan intimidasi. ${ }^{25,26}$
Distribusi sikap siswa berdasarkan hasil pre test dan post test menunjukkan bahwa pada pernyataan sikap positif, siswa paling banyak menjawab sangat setuju akan pentingnya mengikuti penyuluhan tentang bahaya NAPZA, sedangkan pada pernyataan sikap negatif, siswa paling banyak menjawab sangat tidak setuju jika NAPZA akan membuat semakin percaya diri, hebat dan berprestasi. Dari hasil di atas menunjukkan bahwa sikap siswa sebelum dan sesudah diberikan intervensi terjadi perubahan. Perubahanperubahan dalam sikap siswa diantaranya disebabkan oleh pengaruh pelatihan atau edukasi yang dapat mempengaruhi emosi siswa dalam mengambil keputusan atau bertindak.

Hasil uji perbedaan karakteristik responden dengan selisih rata-rata sikap siswa menunjukkan bahwa nilai rata-rata sikap siswa perempuan lebih tinggi dari siswa laki-laki. Hal ini dapat disebabkan karena siswa perempuan lebih antipasti/peka terhadap sesuatu yang baru. Nilai ratarata sikap kelas VIII lebih tinggi dari kelas VII dapat disebabkan karena pengalaman-pengalaman pribadi yang telah dialami sebelumnya. Nilai rata-rata sikap siswa yang tidak pernah terpapar informasi NAPZA lebih tinggi dari siswa yang pernah terpapar informasi NAPZA. Hal tersebut dapat disebabkan dari pengaruh orang lain yang dianggap penting. Nilai rata-rata sikap siswa berusia $>13$ tahun lebih tinggi dari siswa berusia $\leq 13$ tahun kemungkinan disebabkan oleh umur siswa yang lebih tua sehingga mempengaruhi sikap siswa. Siswa yang berusia $>13$ tahun sudah dapat memikirkan segala sesuatu (baik dan buruk) sebelum bertindak. Nilai rata-rata sikap siswa yang memiliki orang tua berlatar belakang pendidikan tidak sekolah-SMP lebih tinggi dari siswa yang memiliki orang tua berlatar belakang pendidikan SMA-Sarjana kemungkinan disebabkan faktor pendidikan dalam keluarga dimana orang tua yang memiliki pendidikan rendah mengharapkan anaknya untuk mengejar pendidikan setinggi-tingginya. Hal tersebut dapat mempengaruhi sikap siswa untuk lebih berhati-hati dalam mengambil setiap keputusan. Nilai rata-rata sikap siswa yang tinggal dengan keluarga lain lebih tinggi dari siswa yang tinggal dengan orang tua. Hal ini dapat sebabkan karena anak-anak yang tinggal dengan orang tua cenderung berperilaku/bertindak sesuka hati mereka berbeda dengan anak yang tidak tinggal dengan orang tua, mereka akan lebih menjaga perilaku mereka.

Pengelompokkan pernyataan sikap tentang penggunaan NAPZA, upaya pencegahan NAPZA serta peredaran NAPZA di sekolah menunjukkan perubahan yang signifikan antara sebelum diberikan intervensi dan sesudah intervensi. Namun selisih kenaikan nilai rata-rata sikap siswa tidak terlalu besar, hal ini kemungkinan disebabkan karena pengaruh salah satu komponen kognitif sikap yaitu pandangan dan keyakinan siswa yang masih sulit untuk diubah. 
Hasil penelitian membuktikan bahwa dengan memberikan intervensi berupa pelatihan modul "Pengenalan Bahaya NAPZA bagi Kesehatan" dapat merubah sikap siswa SMPN 02 Ransiki dalam upaya pencegahan penggunaan NAPZA. Menurut Skinner dalam teori S-O-R, sikap dapat diubah melalui stimulus yang diberikan. ${ }^{21}$ Dalam penelitian ini sikap diubah lewat pelatihan modul yang didalamnya terdapat salah satu elemen dalam perubahan sikap pencegahan penggunaan NAPZA yaitu life skill.

Notoatmodjo menyatakan sikap adalah reaksi atau respon yang masih tertutup dari seseorang terhadap suatu stimulus atau objek. Manifestasi sikap itu tidak dapat langsung dilihat, tetapi hanya dapat ditafsirkan terlebih dahulu dari perilaku yang tertutup. ${ }^{16}$ Sikap siswa SMPN 02 Ransiki mengalami perubahan peningkatan ( $p$ value $0,0001)$ dengan nilai rata-rata pre test $(73,40)$, meningkat pada saat post test $(82,40)$. Berdasarkan teori S-O-R, faktor yang berpengaruh dalam perubahan sikap seseorang adalah stimulus. ${ }^{21}$ Stimulus yang diberikan kepada siswa berupa pelatihan modul. Isi atau materi pelatihan modul yang fokus dalam upaya merubah sikap adalah pada pertemuan ke-4 dengan materi komunikasi persuasif. Komunikasi merupakan salah satu bentuk life skill yang perlu diajarkan kepada siswa atau murid dalam upaya pencegahan penggunaan NAPZA pada kalangan pelajar. Selain itu, berdasarkan teori Health Belief Model, sikap seseorang dapat dipengaruhi oleh keyakinan terhadap gangguan kesehatan dan keyakinan terhadap efektivitas gangguan kesehatan. ${ }^{16}$ Dalam hal ini untuk mempengaruhi sikap siswa diberikan materi tentang bahaya dan upaya pencegahan NAPZA. Penugasan dan games kelompok serta motivasi yang diberikan dari fasilitator turut berpengaruh dalam perubahan sikap siswa.

Hasil penelitian di atas didukung oleh penelitian lainnya yang menyimpulkan bahwa ada perbedaan sikap terhadap perilaku merokok, minum alkohol dan menghisap mariyuana pada siswa sebelum dan setelah mengikuti pelatihan modul kecakapan hidup di SMPN X Jakarta Timur (peningkatan sikap 12,63\%). ${ }^{27}$

SIMPULAN

Ada perbedaan yang signifikan antara rata-rata pengetahuan siswa sebelum dengan sesudah intervensi. Ada peningkatan pengetahuan siswa setelah intervensi sebesar 38,33 . Ada perbedaan yang signifikan antara rata-rata sikap siswa sebelum dengan sesudah intervensi. Ada perubahan sikap siswa setelah intervensi sebesar 9,00. Walaupun intervensi yang telah dilakukan berhasil merubah sikap siswa, namun perlu dilakukan penambahan materi tentang life skill pada pelatihan-pelatihan yang akan dilakukan di kemudian hari sehingga dapat diperoleh sebuah perbandingan.

\section{KEPUSTAKAAN}

1. Nur'artavia, M.R Karakteristik Pelajar Penyalahguna NAPZA dan Jenis NAPZA yang digunakan di Kota Surabaya. The Indonesian Journal of Public Health. 2017; 12 (1) 27-38.

2. United Nation Office on Drugs and Crime. Executive Summary Conclusions and Policy Implications: World Drug Report 2017. United Nations Office on Drugs and Crime: Vienna; 2017

3. Badan Narkotika Nasional. Jurnal Data P4GN 2016 Edisi 2017. Jakarta; 2017 Diambil dari https://ppid. bnn.go.id/wp-content/uploads/sites/2/2019/02/JurnalData-P4GN-2016-Edisi-2017-watermark.pdf

4. Badan Narkotika Nasional dan Pusat Penelitian Kesehatan UI. Hasil Survei Penyalahgunaan dan Peredaran Gelap Narkoba pada Kelompok Pelajar dan Mahasiswa di 18 Provinsi Tahun 2016. Jakarta; 2017

5. Miriam, B. A Pilot Project to Develop a Tool to Assess Gain in Knowledge in Third Graders Participating in a Science Based Drug Prevention Education Curriculum. University of Missouri; 2013 Diambil dari https://remote-lib.ui.ac.id:6066/docview/ 1468712915?accountid $=17242$

6. Nurmaya, A. Penyalahgunaan NAPZA di Kalangan Remaja (Studi Kasus pada 2 Siswa di MAN 2 Kota Bima). Jurnal Psikologi Pendidikan dan Konseling: Jurnal Kajian Psikologi Pendidikan dan Bimbingan Konseling. 2016; 2(1): 26-32.

7. Ardiantina, D. Studi Kasus Kehidupan Remaja Mantan Pecandu Narkoba. Jurnal Bimbingan dan Konseling Universitas Negeri Yogyakarta. 20161 (5): $1-12$.

8. Suranata, K. Pengembangan Model Konseling Logo untuk Mencegah Peyalahgunaan Narkoba, Psikotropika dan Zat Adiktif Lainnya pada para Siswa di Bali. JPI (Jurnal Pendidikan Indonesia). 2013; 2(1): 185-194

9. Sartika, D. Pelaksanaan Layanan Informasi dalam Pencegahan Penyalahgunaan Narkoba di Sekolah Menengah Pertama Tri Bhakti Pekanbaru (Doctoral dissertation, Universitas Islam Negeri Sultan Syarif Kasim Riau); 2014

10. Miriam, B. A Pilot Project to Develop a Tool to Assess Gain in Knowledge in Third Graders Participating in a Science Based Drug Prevention Education Curriculum. University of Missouri; 2013

11. Ayudya, KM., dan Harmanto. Strategi Pembinaan Moral Bagi Siswa Pengguna Narkoba di SMK ABC Surabaya. Kajian Moral dan Kewarganegaraan. 2015; 3 (3): 1308-1323

12. Huang, C., Chien, L., Cheng, C., \& Guo, J. Integrating Life Skills into a Theory-Based Drug Use Prevention 
Program: Effectiveness among junior high students in Taiwan. Journal of School Health.2012;82(7):328-335

13. Riyadi, A. Risiko Penyalahgunaan NAPZA Pada Remaja Ditinjau dari Jenis Kelamin, Status Tinggal, dan Status Orang Tua. 2015: Skripsi. Universitas Muhammadiyah Surakarta.

14. Midford, R., Cahill, H., Foxcroft, D., Lester, L., Venning, L., Ramsden, R., \& Pose, M. Drug Education in Victorian Schools (DEVS): The study protocol for a harm reduction focused school drug education trial. BMC Public Health. 2012; 12(2): 112118. doi:http://dx.doi.org/10.1186/1471-2458-12-112

15. R.K, Jorma I.V. Patterns of pretreatment drug abuse, drug treatment history and characteristics of addicts in methadone maintenance treatment in Iran. Harm Reduction Journal.2012; 9 (18):1-7.

16. Notoatmodjo, S. Ilmu Perilaku Kesehatan. Jakarta : PT. Rineka Cipta; 2012

17. Wawan, A. \& Dewi, M. Teori dan Pengukuran Pengetahuan, Sikap, dan Perilaku Manusia. Yogyakarta: Nuha Medika; 2010

18. Shekarchizadeh, H., Hamed E, Mohammad R.K, Jorma I.V. Patterns of pretreatment drug abuse, drug treatment history and characteristics of addicts in methadone maintenance treatment in Iran. Harm Reduction Journal . 2012;9 (18): 1-7.

19. Hernawan, A. H., Permasih, H., \& Dewi, L. Pengembangan Bahan Ajar. Direktora UPI: Bandung; 2012 Diambil dari http://file.upi.edu/Direktori/FIP/ JUR._KURIKULUM_DAN_TEK._PENDIDIKAN/19 4601291981012-PERMASIH/PENGEMBANGAN_ BAHAN_AJAR.pdf
20. Wina, S. P. Efektifitas Pendidikan Kesehatan terhadap Peningkatan Pengetahuan Siswa SMP tentang NAPZA. Repositori UNRI; 2013. Diambil dari https://repository.unri.ac.id/bitstream/handle/1234567 89/1826/jurnal.pdf;jsessionid=C7AD356A98B35DDB BFADFB27BCCD615E? sequence $=1$

21. Skinner, B.F. The Behavior of Organisms: An Experimental Analysis. Cambridge: B.F. Skinner Foundation; 2019

22. Carolina, M., Rahayu, S. M., \& Resti, E. R. Pengaruh Pendidikan Kesehatan Terhadap Tingkat Pengetahuan Siswa Tentang Bahaya Napza Di Madrasah Aliyah Miftahul Jannah Kelurahan Pahandut Seberang Kota Palangka Raya. Dinamika Kesehatan Jurnal Kebidanan Dan Keperawatan. 2016;7(2): 110-123.

23. Sarwono, S.W. Psikologi Remaja. Jakarta: Rajawali Pers; 2012

24. Susanto, A. Bimbingan dan Konseling di Sekolah: Konsep, Teori, dan Aplikasinya. Jakarta: Prenadamedia Group; 2018

25. Departemen Pendidikan Nasional. Pedoman pelatihan dan modul pendidikan pencegahan penyalahgunaan narkoba .Jakarta: Depdiknas; 2013

26. Srikala, B., \& Kishore, K. K. Empowering adolescents with life skills education in schools-School mental health program: Does it work?. Indian Journal of Psychiatry. 2010; 52(4): 344-349.

27. Santosa, E. T., Atmodiwirjo, E. T., \& Soetikno, N. Efektivitas Kecakapan Hidup Sebagai Pencegahan Penyalahgunaan Tembakau, Alkohol, dan Mariyuana (Studi pada Siswa/i SMPN X). Provitae. 2017; 5(1): 89-96. 